\title{
Aspect of Dynamic Simulation and Experimental Research Studies on Hybrid Pneumatic Power System
}

\author{
K. David Huang ${ }^{1}$ and Hoai-Nam Nguyen ${ }^{2}$ \\ ${ }^{1}$ ReD Center of Vehicular Ultra Low Carbon Energy and Systems, National Taipei University of Technology, Taipei 010000, Taiwan \\ ${ }^{2}$ Department of Mechanical Engineering, University of Economic and Technical Industries, Hanoi 000222, Vietnam
}

Correspondence should be addressed to Hoai-Nam Nguyen, nhnam.uneti@moet.edu.vn

Received 24 August 2009; Accepted 6 April 2010

Academic Editor: Rakesh Mishra

Copyright $\odot 2010$ K. D. Huang and H.-N. Nguyen. This is an open access article distributed under the Creative Commons Attribution License, which permits unrestricted use, distribution, and reproduction in any medium, provided the original work is properly cited.

\begin{abstract}
A Hybrid Pneumatic Power System (HPPS) has been developed for several years with the major aim of reducing the vehicle fuel consumption, environment pollution and enhancing the vehicle performance as well. Comparing with the conventional hybrid system, HPPS replaces the battery's electrochemical energy with a high-pressure air storage tank and enables the internal combustion engine (ICE) to function at its sweet spot. Besides, the HPPS, which effectively merges both the high-pressure air flow from the storage tank and the recycled exhaust flow from the ICE, thereby increases the thermal efficiency of the ICE and transforms the merged flow energy into mechanical energy using a high-efficiency turbine. This paper focuses on the major research process into HPPSs, including overall dynamic simulation and experimental validation. By using the simulation tool ITI-Sim, this research demonstrates an experiment which can be operated precisely according to the requirements of various driving conditions under which a car actually runs on the road in accordance with the regulated running vehicle test mode. HPPS is expected to increase the performance of the entire system from $15 \%$ to $39 \%$, and is likely to replace the traditional system in the coming years.
\end{abstract}

\section{Introduction}

The development of the vehicle industry and conventional engines has gained many important achievements, especially at the end of the twentieth and beginning of the twenty-first century. However, such rapid development of the industry, with an increasing number of vehicles in not only developed countries but also developing ones, such as India, China, Vietnam, and so on, has resulted in many negative effects on modern society as well as on human lives. For instance, global warming and air pollution as well as climbing fuel prices have recently become serious problems. More and more stringent emissions and fuel consumption regulations are stimulating an interest in the development of safe, clean, and high efficiency transportations, including Electric Vehicles (EVs), Hybrid Electric Vehicles (HEVs), and Fuelcell Electric Vehicles (FEVs), which offer the best possibilities for use of new energy sources [1-3]. Nonetheless, both zeropollution electronic and gas-electric hybrid vehicles have disadvantages in that the energy is stored in the battery cell only in the form of electrochemical energy $[4,5]$. In particular, the battery cannot be fully charged rapidly. Additionally, neither a hybrid power engine nor a direct injection engine can enable the internal combustion engine (ICE) to operate stably in an optimal state. Also, the waste heat of the ICE is not recycled effectively. Recycling of used fuel cells does not currently occur. So, this technology cannot be commercialized with a lower production cost than that of ICE.

Some other new technologies have been developed to overcome the above disadvantages. During the Paris International Vehicle Fair held in October 2002, a minitype pneumatic power vehicle driven by compressed air in lieu of fuel attracted the attention of the world, which indicated et [6]. The biggest difference between the compressed-air engine and the traditional gasoline engine lies in the fact that the engine of the air-powered vehicle is driven by expansion of the compressed air while the traditional engine is powered by the released energy of mixed gasoline and air. Furthermore, because of its long range, the air-powered vehicle can satisfy the demands of many drivers. In December 


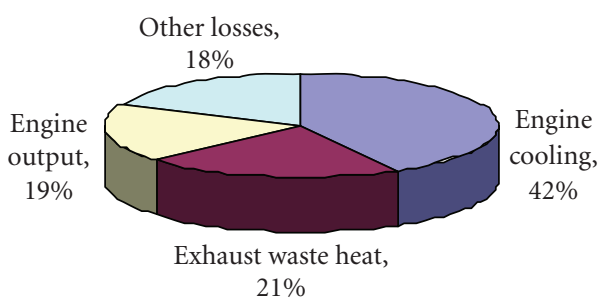

$1500 \mathrm{rpm}-1 / 4$ load

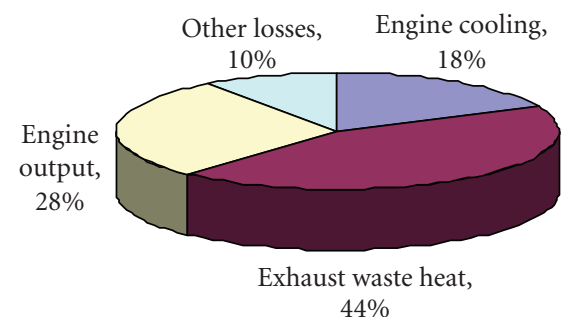

4500 rpm-full load

Figure 1: Losses of traditional ICE engine [19].

2006, two delivery trucks were developed in a joint project involving the U.S Environmental Protection Agency (EPA), UPS, and Eaton Corp. A hydraulic system replaces the battery for energy storage. As mentioned in [7], a major benefit of a hydraulic hybrid vehicle is fuel economy improvement due to the vehicle's ability to capture energy normally lost in vehicle braking. The hydraulic system can capture and store more than $76 \%$ of the energy normally wasted in vehicle braking and use this energy to help propel the vehicle during the next vehicle acceleration. Sufficient energy is stored to allow the truck to move several hundred feet with the engine off. This is adequate for some UPS deliveries.

However, from the perspective of researchers, up to now neither a zero-pollution vehicle nor a green engine can currently enable the ICE to operate stably at its optimal operating point. In addition, heat from exhaust gases from engines has still not been used effectively or researched without being verified carefully. As indicated in [8-11], over $70 \%$ of the initial energy from fuel can not be converted to mechanical energy, and is instead mainly directed to other parts of the engine in the form of heat or emitted as exhaust gases. These results in the energy efficiency of vehicles equipped with the ICE being as low as 15\%, according to [12].

In order to solve the aforementioned problems, a HPPS is proposed, which is integrated with an ICE, an air compressor, a high-pressure air storage tank, an energy merger pipe, and a high-efficiency turbine. This system stores the flow energy instead of storing a battery's electrochemical energy. Furthermore, it can recycle the exhaust gas energy and make the ICE operate at an optimal state of maximum efficiency. According to the energy estimated calculation as shown in Figure 1, vehicle quipped with an HPPS could achieve efficiency approximately 24\% higher than that of conventional vehicles. Thus, the HPPS can be considered a promising solution to increase the thermal efficiency and greatly improve exhaust emissions.

\section{System Concept}

As illustrated in Figure 2, the primary difference between the power train of HPPS and a conventional hybrid system is the replacement of the generator with the compressor. The high pressure compressed air powered cylinder tank replaces the battery, and an air turbine replaces the electric

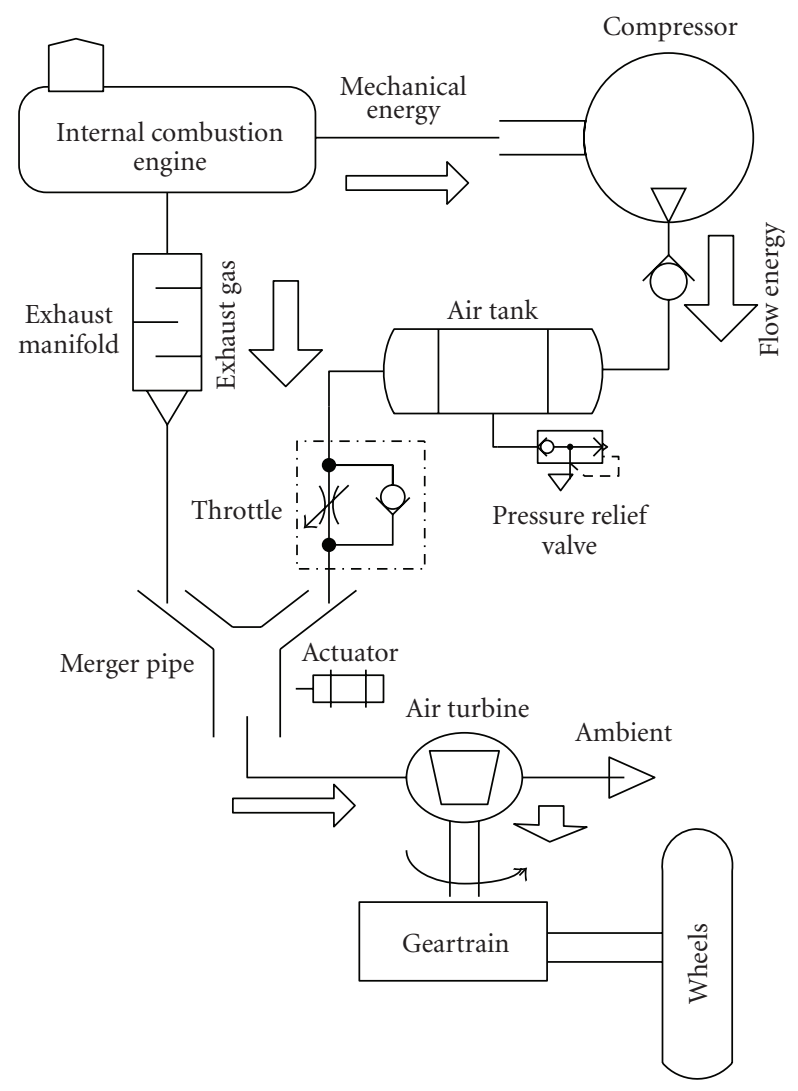

FIgure 2: The concept of HPPS.

motor. Rather than combining an ICE and an air compressor, this innovation has adapted an engine to match the air compressor, and in this manner compresses the air directly into an air storage tank for pressure stabilization and energy storage. Then, the compressed air will flow through a throttle valve, regulate the airflow, and activate the air turbine according to the opening angle of the throttle valve. Passing the throttle valve, the compressed air will flow through a merger pipe, where the compressed air will mix with the high temperature waste gas of the ICE.

The recycling capabilities of the exhaust gas depend significantly, however, on the flow energy merger in the system. In the HPPS operating process, a more highly pressured air flow from the air-tank side will obviously lead 
to the static pressure in the merging region of the merger pipe being too high, which prevents the exhaust gas flowing out. In some cases, the exhaust gas cannot flow out as well as the engine is affected in a negative way by high-pressure air from the air tank. Thus, to avoid unexpected phenomena, the cross sectional area at the merger-pipe device will be adjusted by the actuator E-motor, which is described more clearly in $[13,14]$. The high efficiency turbine is then driven by the mixing air to generate sufficient power via the gear train acquired from the wheels.

With the aim of absorbing waste heat from the ICE in order to increase the flow energy significantly, this system will not only improve the thermal efficiency of the engine by recycling its waste heat, but also reduce the exhaust emissions of the engine. In the scope of current research, the regeneration system upon vehicle deceleration were not taken into account. Besides, the engine is started with a conventional electric starter, which is not to be shown in the concept.

\section{Theoretical Analysis}

3.1. Internal Combustion Engine. The system uses the $125 \mathrm{cc}$, one cylinder, four-stroke engine manufactured by SYM Corporation. According to the producer, the engine reaches the lowest brake specific fuel consumption (BSFC) by $5000 \mathrm{rpm}$, 4.76 PS, which is the sweet spot of this engine. Throughout the experiment and simulation, the engine always works at this optimal condition. This results in an increase in the economic efficiency of energy consumption as well as a significant decrease in exhaust gases such as $\mathrm{CO}, \mathrm{CO} 2$, $\mathrm{HC}$, and PM. The brake horse power of the engine can be calculated by the following equation:

$$
\mathrm{BHP}=\frac{2 \pi N T}{60 \times 75}=\frac{T N}{716}=0.0014 T \times N .
$$

3.2. Air Compressor. The pneumatic power system analyses and simulates a two-state reciprocating compressor. The outstanding operating point of such a compressor in comparison with the screw compressor is the capacity of the former to provide high pressure in a short period of time. This is reasonable for providing sufficient energy for the air storage tank under any condition. The work done on the compressor shaft under polytropic condition can be calculated as follows:

$$
\begin{aligned}
W & =\frac{n}{n-1} P_{0} V\left[\left(\frac{P_{1}}{P_{0}}\right)^{(n-1) / n}-1\right] \\
& =\frac{n R T_{1}}{n-1}\left[\left(\frac{P_{1}}{P_{0}}\right)^{(n-1) / n}-1\right] .
\end{aligned}
$$

The volumetric efficiency of the reciprocating compressor is a function of the first state geometry, although for the simulation purposes, the separate states can be separately analyzed. It is given by:

$$
\eta_{v}=K\left[1-V_{c}\left\{\left(\frac{p_{2}}{p}\right)^{(1 / m)} \frac{Z_{1}}{Z_{2}}-1\right\}\right] .
$$

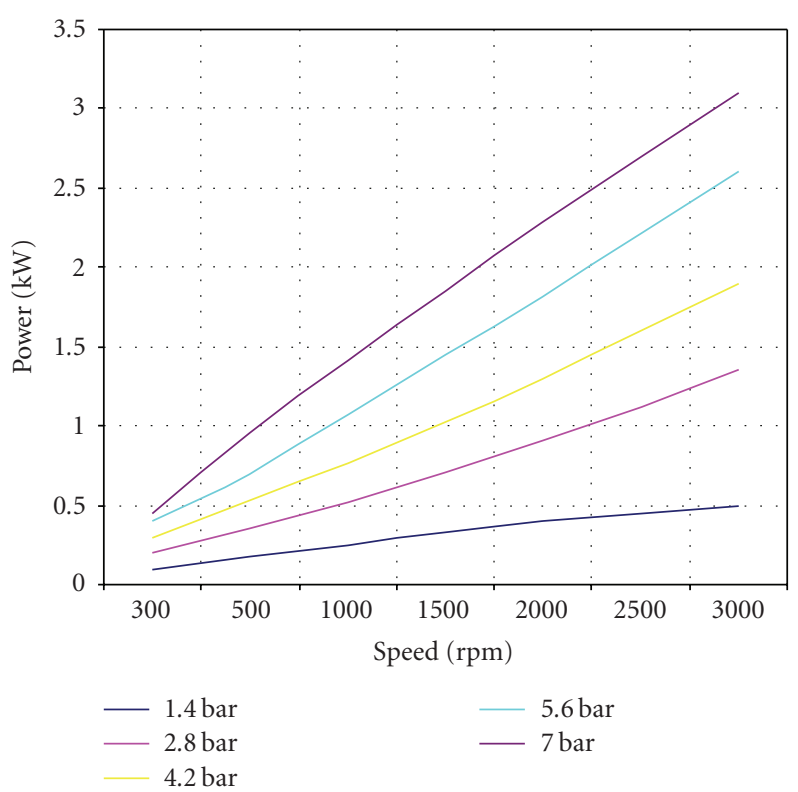

Figure 3: Air-Turbine Power Characteristic.

3.3. Air Storage Tank. The air tank in HPPS should be atleast large enough to hold all the air delivered by the compressor. Received size of the tank can be calculated as follows: (with considering the volumetric efficiency and for constant delivery compressor)

$$
V r=\frac{Q \times P_{o}}{P_{d}}=\frac{Q}{P_{d}} .
$$

As $P_{a}$ is taken as 1 bar for easy calculation.

3.4. Air Turbine. The outstanding overall efficiency of air turbine inside HPPS, compared to other type of motor such as electric motor and so on, is one of the advantage points of this system, which can reach an optimal efficiency of up to $78 \%[15]$.

Due to the lack of a theoretical formula for the simulation of the air turbine model's behavior, the simulation is essentially based on the performance curve provided by GAST Manufacturing (6AM-ARV-55) as in Figures 3 and 4. The five different curves represent different pressures. When the pressure is increased from 1.4 to 7 bar, the maximum power is also increased from 0.5 to $3 \mathrm{~kW}$, and the maximum torque from 1.5 to $13 \mathrm{Nm}$. Accordingly, the theoretical net efficiency $\eta$ can be calculated by the following equation:

$$
\eta=\frac{\omega T}{\Delta P M} .
$$

3.5. Impact Factor from Outside Environment. According to the analysis of Wong in Theory of Ground Vehicle [16], the fundamental environment-related impacts on vehicles are rolling resistance under the effect of tires, road surface, and aerodynamic resistance due to the external shape of vehicles. 


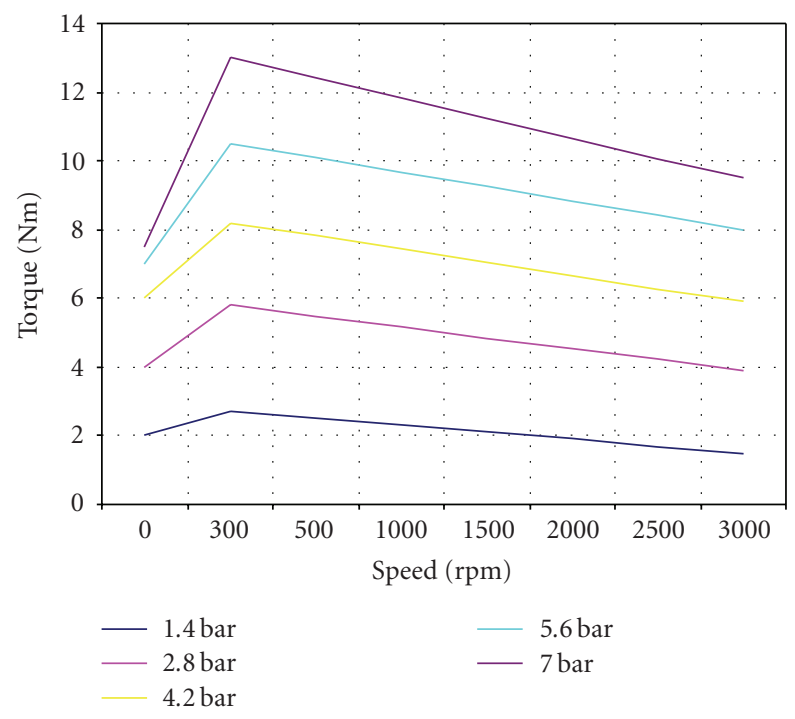

FIgure 4: Air-Turbine Torque Characteristic.

Aerodynamic resistance is usually expressed in the following form:

$$
R_{a}=\frac{\rho}{2} C_{D} A_{f} V_{r}^{2}
$$

For an individual wheel, the rolling resistance on the wheel is defined as

$$
R_{r}=\mu_{r} W_{w} .
$$

The friction coefficient and slip characteristic between tire and road depend significantly on the road condition of dry, wet and so on, which have been defined in [17] according to the following equation:

$$
\begin{aligned}
\mu\left(\lambda_{x}\right)= & A\left(1-e^{-B \times \lambda_{x}}\right) \\
& -\left[\frac{0.01 \times K \times e^{r \times \lambda_{x}}}{(K-0.01)+0.01 \times e^{r \times \lambda_{x}}}-0.01\right] .
\end{aligned}
$$

\section{HPPS Simulation with ITI-SIM}

Developing simulation models for Hybrid Pneumatic Power System implies the inclusion of the different physical components of the power-train, ranging from mechanics, for instance the internal combustion engine and automotive components, to pneumatics such as compressor, pneumatic air tank, gas turbine, or even the consideration of the involved control systems. For all of these fields there exist different established modeling approaches. From the point of view of system simulation, three core approaches can be distinguished:

4.1. Physical Modeling. A structurally motivated partitioning of the overall system finally leads to a separation into physical elements. The interconnection between the objects is noncausal and is defined by the balance equations for potential and flow quantities of the respective physics. This way of modeling preserves the physical relationships between the elements in the model structure. Any researcher familiar with the system will immediately understand the layout of such a model, and will know where parameters are applied and where the physical result quantities are found.

4.2. Signal Modeling. In signal modeling the behavior of the system under study is implemented into a block structure. The blocks communicate to each other in a strictly causal (directed) manner and, consequently, there are clearly assigned inputs and outputs on the blocks. Signal modeling is the method of choice for mapping control systems.

4.3. Equation-Based Modeling. The function of subsystems and components in a system can also be described directly by differential equations. If a simulation environment does not provide a predefined element covering a particular physical relationship, this approach is the straightforward way to include its functionality into the simulation model

While starting the simulation of the entire HPPS, the research group realized that objects which need to be simulated including all three characteristics above and, therefore, the software ITI Sim, which has the capacity to apply the best fit to each component of the system [18], has been used to simulate the whole HPPS. In this paper, simulations were performed using a commercial ITI Sim (ITI Company, version 3.5) on a Windows XP-based Intel Code 2 Duo(3.5 GHz, 3 GB RAM).

As can be seen in Appendix B, ICE is a model of a onecylinder, four-stroke gasoline engine with a rigid crank shaft and an engine control unit. Such a model has been designed and is available from the library of ITI Sim, and commonly available specified data can be used for the parameter input for the motor. The model works with a normalized torque curve which takes the nonuniformities during ignition and compression into account. The speed dependency and the effect of stepping on the gas are also superimposed on the torque curve.

The model meets the design's technical requirement of fixing the turning speed of the ICE at the sweet spot, reaching the lowest brake specific fuel consumption and also the optimal operating point of engine. Here, the control signal is transferred for the gas factor at two conditions: no injection or full load. The feedback signal for the model is provided by the pressure sensor of the air storage tank model. Models of the air compressor and turbine are also indicated. Because ITI provides insufficient models for the air compressor and turbine, their specific characteristics are divided into different objects and analyzed separately. Residues in the air compressor as well as the turbine are analyzed in the friction model. Vehicles as well as driving resistances are illustrated, including vehicle mass, rolling resistance, and aerodynamic resistance as well as the wheels-ground contact between vehicle tire and road. The fundamental parameters of this system are illustrated in Tables 1 and 2. Heat transfer in each object in the system is also mentioned, including the heat transfer coefficient, surface area, and wall temperature. 
TABLE 1: Assumed values of the pertinent parameters to various components.

\begin{tabular}{lc}
\hline Parameter & Value \\
\hline Optimal mode of the ICE & $3.5 \mathrm{~kW}$ \\
Rotational inertia of flywheel & $5000 \mathrm{rpm}$ \\
& $0.5 \mathrm{~kg} / \mathrm{m}^{2}$ \\
Ideal air condition (ambient pressure and temperature) & $1 \mathrm{bar} @$ \\
& $20^{\circ} \mathrm{C}$ \\
Frictional resistance of air compressor & $2 \mathrm{Nm}$ \\
Mechanical efficiency of air compressor & $80 \%$ \\
Volume of storage tank & $105 \mathrm{liters}$ \\
Efficiency of air turbine & $75 \%$ \\
Frictional resistance of air turbine & $2 \mathrm{Nm}$ \\
Allowable exhaust-gas backpressure & $0.5 \mathrm{bar}$ \\
\hline
\end{tabular}

TABLE 2: The parameters of the simulated motor vehicles.

\begin{tabular}{lc}
\hline Parameter & Value \\
\hline Motorcycle's mass & $140 \mathrm{~kg}$ \\
Rider's weight & $70 \mathrm{~kg}$ \\
Headwind speed & $5 \mathrm{~m} / \mathrm{s}$ \\
Radius of the rear wheel & $0.2 \mathrm{~m}$ \\
Windward area of the rider & $0.3 \mathrm{~m}^{2}$ \\
Windward area of the Motorcycle & $0.4 \mathrm{~m}^{2}$ \\
Coefficient of wind resistance & $0.69 \mathrm{Ns} / \mathrm{kg}$ \\
Air density & $1.22 \mathrm{~kg} / \mathrm{m}^{3}$ \\
\hline
\end{tabular}

\section{Experimental Study}

In order to validate the accuracy of the simulation, the study of HPPS experiment has been conducted. As illustrated in Figure 5, the experiment layout includes a four-stroke gas engine (1), a reciprocating air compressor (2), an air storage tank (4), and a turbine (7). The outstanding point of this experiment is that the research group carried out a smart design with a new energy merger pipe whose influence was analyzed in [8]. Detailed information about the parameters of each device is listed in Table 3. However, in this experiment, due to the lack of a appropriate turbine to meet the design requirements, the research group concentrated on studying and experimenting on engine impacts, compressor operating accuracy, and the pressure accumulation process as well as the capacity for recycling the heat energy from exhaust gas

Temperature sensors, pressure sensors, and torque sensors are installed in reasonable positions, as can be seen in Figure 5, to receive the signals in the experiments. Signals from temperature and pressure sensors are transmitted to a Testo 400 Device after passing the intermediary transformer $\mathrm{A} / \mathrm{D}$ with a frequency of 1 second, and then digitalized on the PC using instruNet.

The signal from the torque sensor is similarly digitalized and communicated through the PC and Comsoft 3 software. In the experiment, ICE always works well at the optimal speed of up to $5000 \mathrm{rpm}$. All the experiments above are carried out three times in order to minimize errors as well
TABle 3: The Experiment parameters.

\begin{tabular}{lc}
\hline Parameter & Value \\
\hline Gasoline engine (SYM) & $125 \mathrm{cc}, 4$-stroke \\
Max input of air compressor & $10 \mathrm{PS}$ \\
Max output of turbine & $15 \mathrm{PS}$ \\
Load cell & $25 \mathrm{Nm} 3600 \mathrm{rpm}$ \\
Electric motor (force, itinerary) & $30 \mathrm{~N}, 30 \mathrm{~mm}$ \\
Torque sensor & Kyowa $0-50 \mathrm{Nm}$ \\
Air tank & 105 liters \\
Temperature sensor & $0-1000 \mathrm{C}$ \\
Pressure sensor & $0-10 \mathrm{bar}$ \\
Flow meter sensor & $0-60 \mathrm{~m} / \mathrm{s}$
\end{tabular}

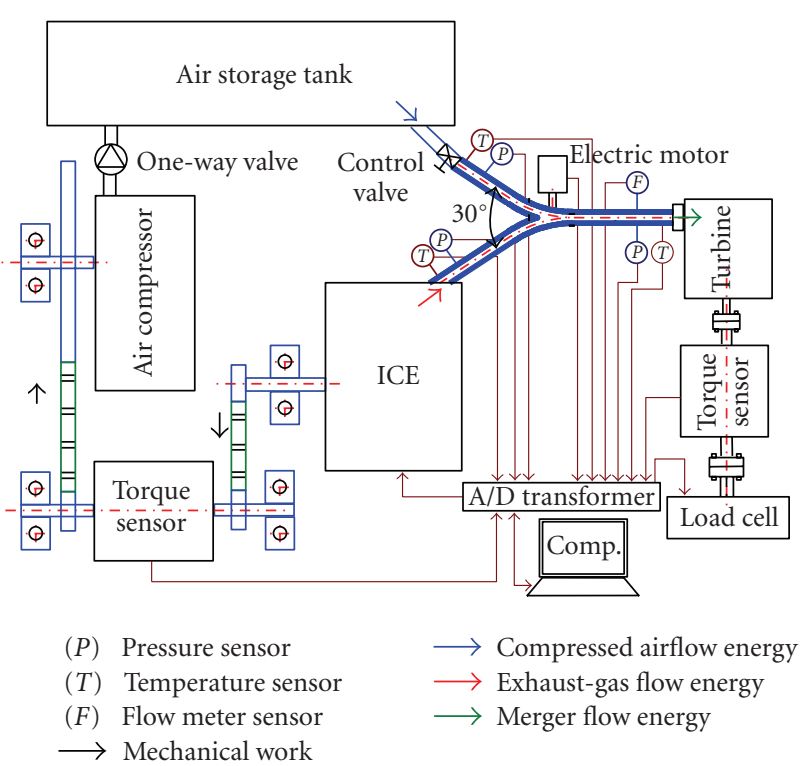

Figure 5: Schematic layout of the experimental setup.

as obtain results that are as accurate as possible. For instance, in the dynamic load test, when the air compressor starts to operate, the test takes place repeatedly from three to five times in order to find the right time at which the engine works well under sufficient load.

\section{Results}

6.1. Affects from the Simulation Results. As shown in Figure 6, the rotational speed will climb to its maximum value of $5500 \mathrm{rpm}$, after approximately $1.8 \mathrm{~s}$ upon the activation of the internal-combustion engine. In this case, the operating point is not the optimal one, because the back pressure between that in the air compressor and the pipeline has not yet reached its preset pressure, and the air compressor has a somewhat smaller load than the internal-combustion engine, so the rotational speed will exceed that at its optimal operating point. Then, the rotational speed will become roughly stable after about $6 \mathrm{~s}$, although it will still fluctuate slightly around $100 \mathrm{rpm}$. This is because the internal combustion engine has to stimulate the air compressor to make it reach its 


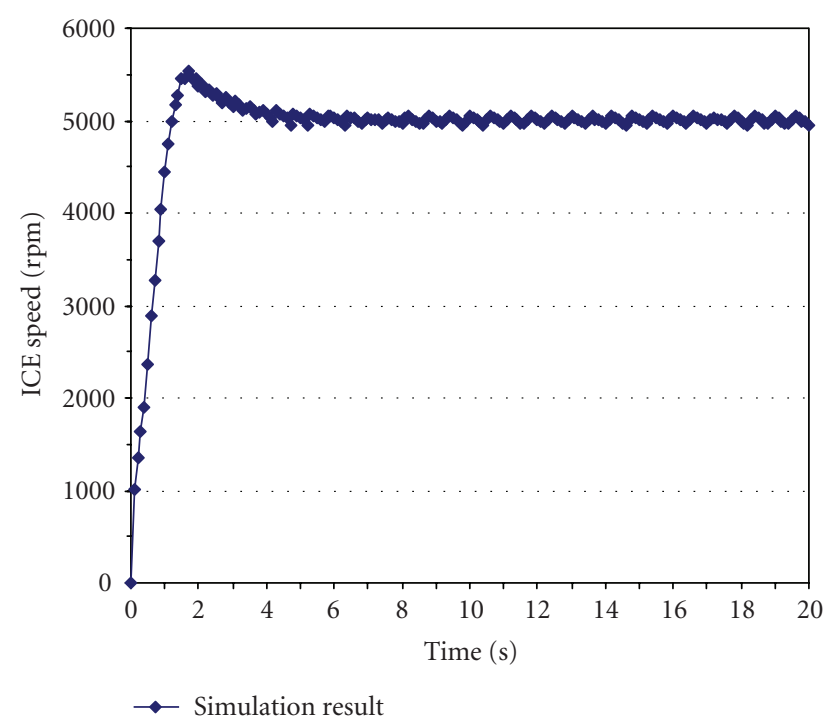

FIgURE 6: Output Speed of the ICE.

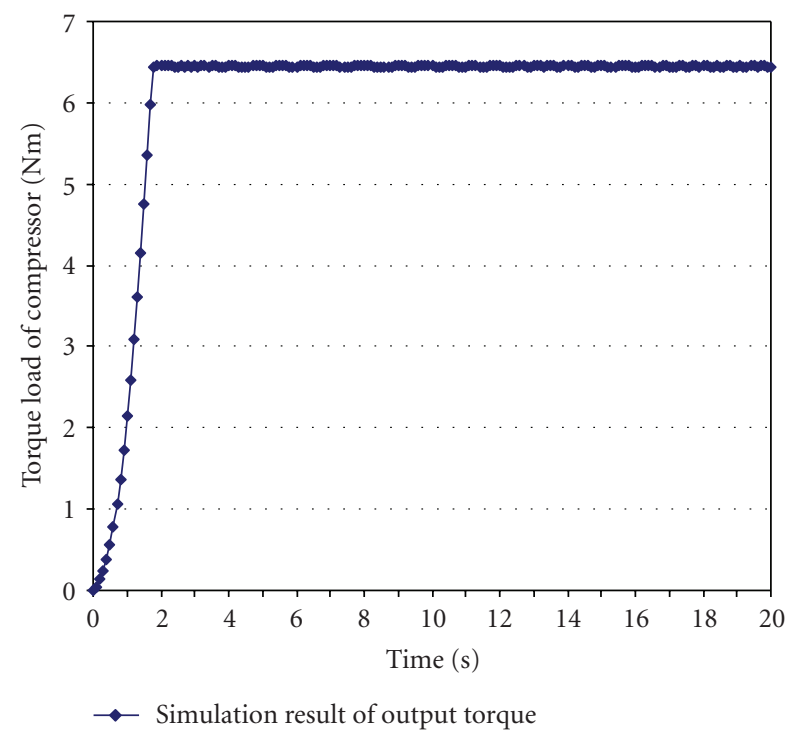

FIgURE 7: Torque load of the compressor.

rated pressure value while overcoming its resistance during this stage. At this point, the pressure-control valve will enable the compressed air to yield a pulse, then the power required by the compressor and the load of the internal-combustion engine will fluctuate consequently.

In view of the air compressor, Figure 7 illustrates the axial load of the engine in the simulation. The torque delivered to the air compressor become stable, maintaining load at $6.7 \mathrm{Nm}$ and actually fluctuating by $\pm 0.25 \mathrm{Nm}$ right after having worked at $5000 \mathrm{rpm}$. As can be seen in Figure 8 and Figure 9, the curves showed the output mass flow rate of the compressor as well as its output temperature. It is obvious that the compressor operating state can guarantee a stable air-output and temperature output when the rated value is realized. In addition, from the torque load of the compressor and the output mass flow rate of the compressor, we can

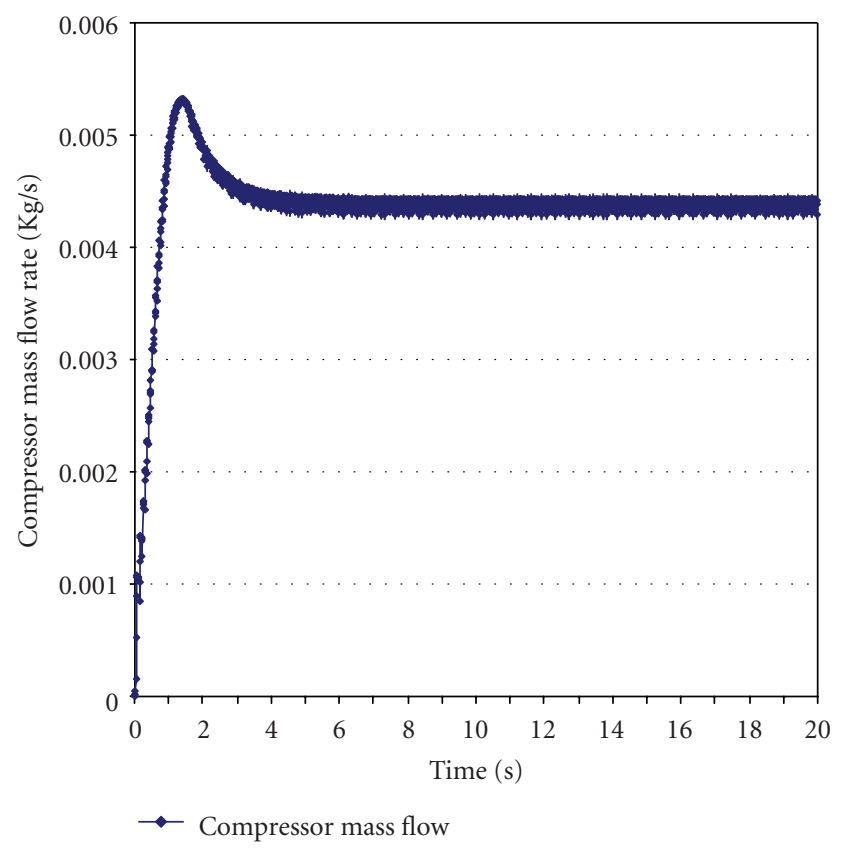

Figure 8: Mass Flow Rate of the compressor.

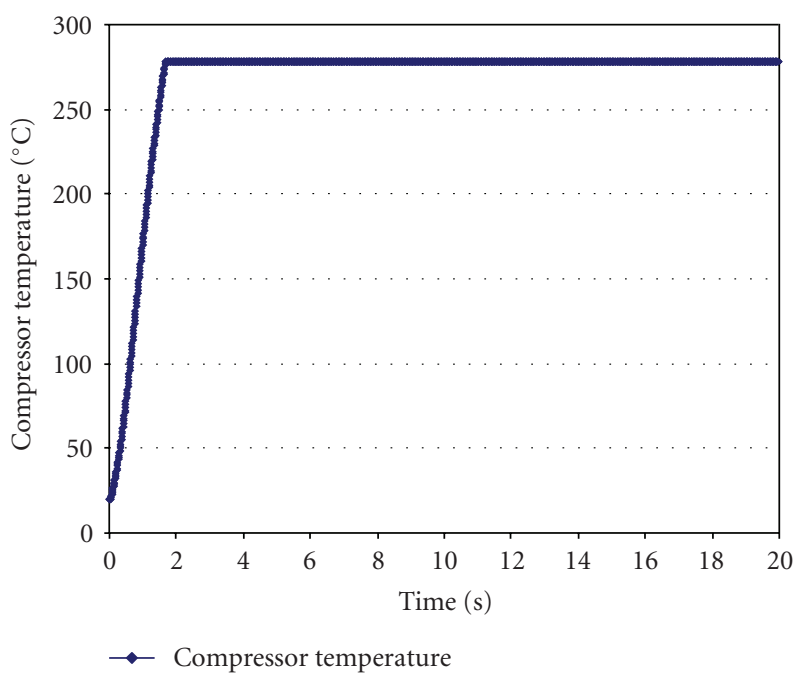

FIGURE 9: Output temperature of the compressor.

see that there is a positive correspondence between the air output and torque load as well as the rotational speed. If the outlet pressure pulsation of the compressor is reduced, the load on the internal-combustion engine and the air output of the compressor will cut down their variations accordingly, thus making it possible for the internal-combustion engine to operate steadily in the optimal state.

As illustrated in Figure 10, the filling-up speeds (time for the pressured air reaching the maximum point within the air stogare tank) of the air stogare tank have been illustrated at different output speeds of the internal combustion engine (ICE) crank-shaft. In the simulation, the volume of the tank has taken the same volume of the tank in experiment into account. In the chart, it can be observed that the air, or the flow energy storing of the air storage tank increases rapidly 


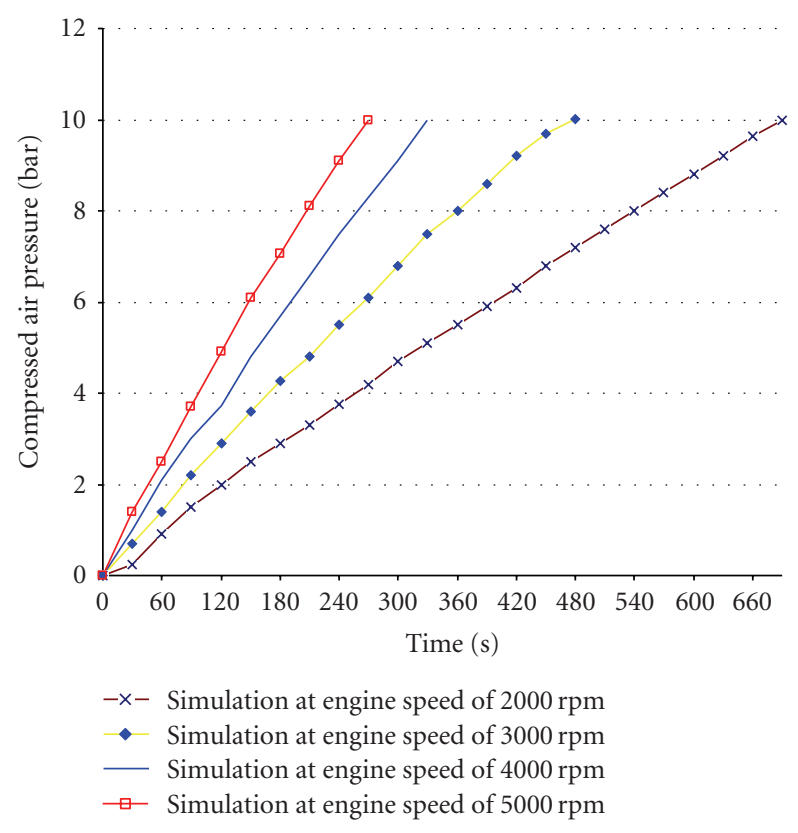

FIgURE 10: Filling up speed of the air storage tank.

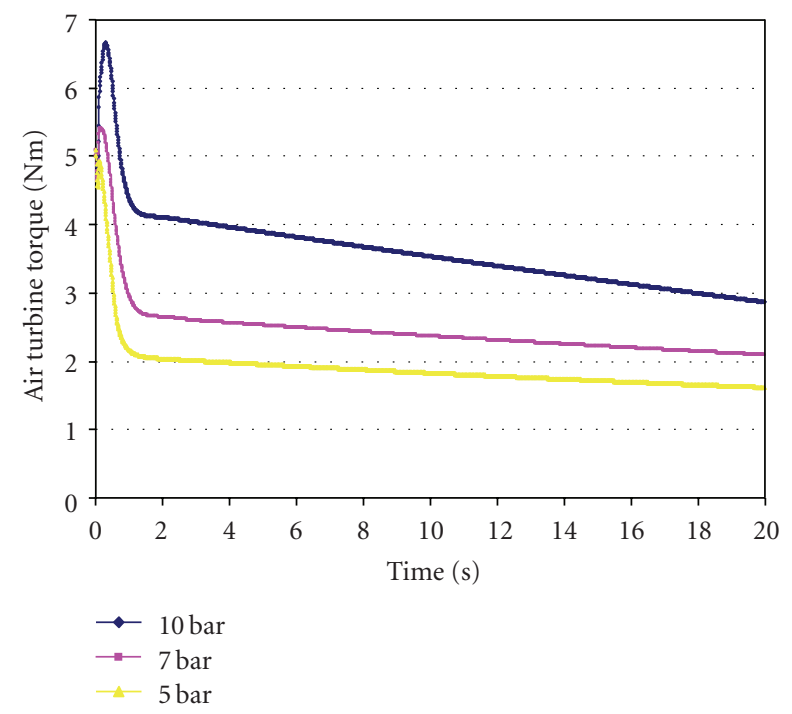

FIgure 11: Output Air Turbine Torque.

when the ICE operates at a high speed of $5000 \mathrm{rpm}$. This is because the mass flow rate of the compressor charges into the air storage tank accordant with the out put speed of the engine. When the ICE operates at optimal speed of $5000 \mathrm{rpm}$, the pressure in the air storage tank reaches ten bars within approximately $270 \mathrm{~s}$, whereas it needs nearly $700 \mathrm{~s}$ in the engine speed of $2000 \mathrm{rpm}$. This result indicates that the flow energy storing of the air storage tank in the HPPS can be fully charged rapidly compared to the conventional hybrid vehicle.

As can be seen in Figures 11 and 12, the output torque and air turbine revolution at various working pressure of 5 bars, 7 bars, and 10 bars have been evaluated. It obvious that a smaller slope of the pink line represents a mild output torque around $2.5-3 \mathrm{Nm}$. Besides, there is a bigger incline

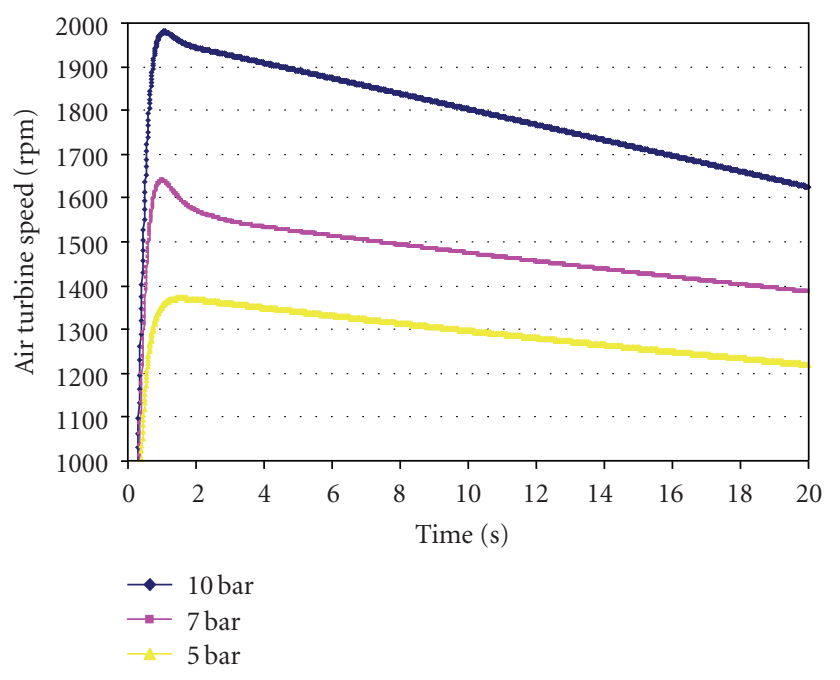

Figure 12: Output Air Turbine Speed.

of the green line between 0 and $10 \mathrm{~s}$ in the simulation, the output torque amounts to $3-4 \mathrm{Nm}$, because at the beginning, the pressure in the air storage tank has not achieved an equilibrium between supply from the compressor and demand at the opening of throttle, leading to the failure of a proper combination between the opening angle of the throttle valve and power output. As soon as the slope becomes more stable after $14 \mathrm{~s}$, the output torque amounts to $2.5-3 \mathrm{Nm}$. When the slope of the pink line becomes smaller and more stable after $14 \mathrm{~s}$, the output torque becomes 2.3-1.8 Nm. In addition, the initial output torque of the green line at 7 bars got the largest number of approximately $7 \mathrm{Nm}$, the initial output torque of the pink and yellow ones got around $5 \mathrm{Nm}$. This is because there is a big frictional resistance and a rapidly declining rotational speed in the case of the high-speed output of the pneumatic motor.

6.2. Impacts of Operating Conditions to the Vehicle. This part concentrates on evaluating the impact of important parameters throughout the experiment and operation, including: controlling the valve's aperture for compressed air, or throttle, with apertures of $25 \%, 50 \%, 75 \%$, and $100 \%$; the aperture of the valve to the compressed air tank before the engine operation remains stable at 8 bars, 10 bars, and 12 , bars (it is noticeable that the pressure of the air storage tank remains at 10 bar in the experiment); and vehicle velocity (due to the different aperture of the throttle and the different pressure in air storage tank).

Apparently, as can be seen in Figure 13, when the throttle stays at $100 \%$, the preset pressure of the air storage tank is analyzed at 8 bars, 10 bars, and 12 bars for a period of $60 \mathrm{~s}$. In the first $30 \mathrm{~s}$, the velocity increases dramatically due to high pressure in the air storage tank. Moreover, when the air flow is wholly compressed into the turbine at full throttle, the vehicle's velocity suddenly changes. However, after $30 \mathrm{~s}$, velocity increases gradually and tends to decline slightly. Velocity remains stable at $105 \mathrm{~km} / \mathrm{h}, 84 \mathrm{~km} / \mathrm{h}$, and $72 \mathrm{~km} / \mathrm{h}$ with pressures of up to 12 bars, 10 bars, and 8 bars, respectively. One factor causes this phenomenon. The 


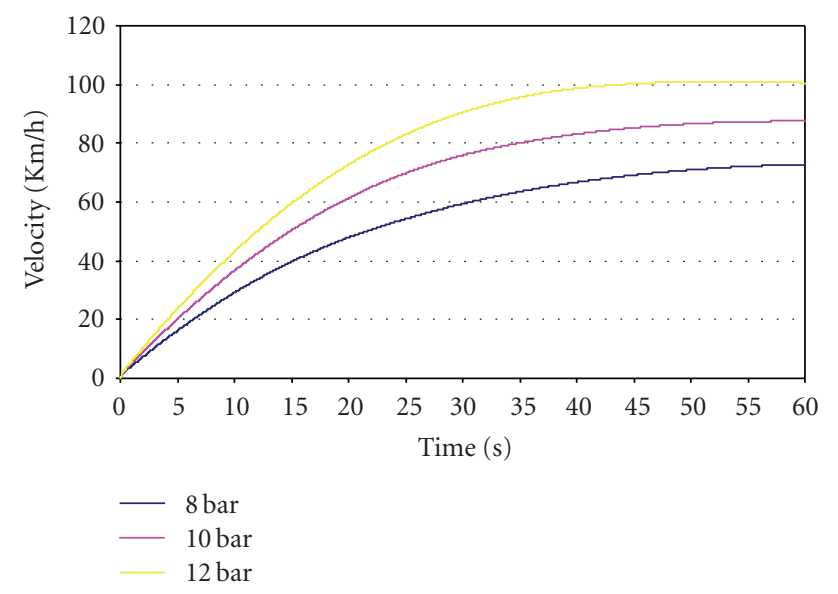

FIGURE 13: Velocity of the motor vehicles in various preset air storage tank's pressure when throttle stays at $100 \%$.

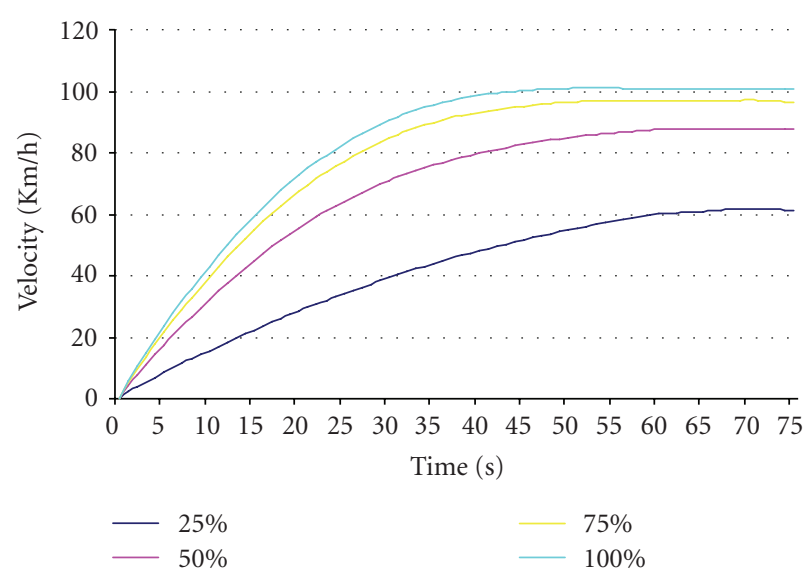

FIgURE 14: Velocity of the motor vehicles in various throttles.

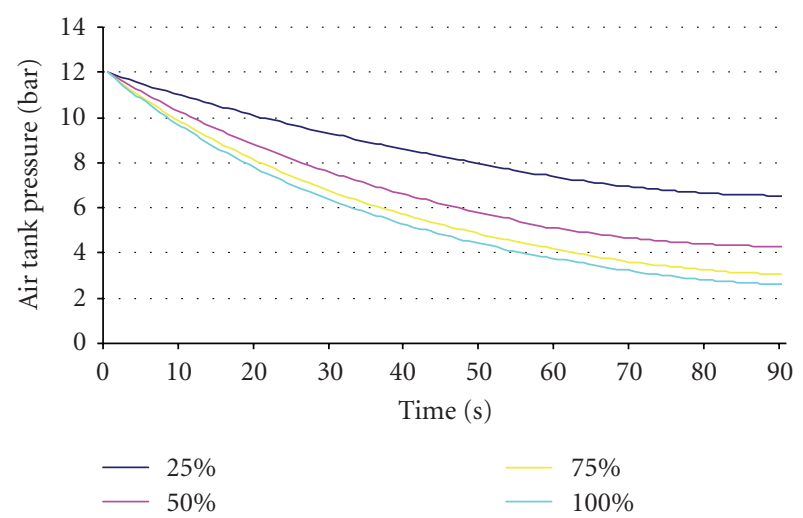

FIgURE 15: The decrease in pressure of air storage tank.

pressure in the air storage tank plummets and remains stable when the pressure provided by the compressor gradually equilibrates with the outlet pressure. In brief, after the first $30 \mathrm{~s}$ or $40 \mathrm{~s}$, pressure in the air storage tank reaches equilibrium However, according to [11], full throttle results in a negative phenomenon in the cross-sectional area (CSA)

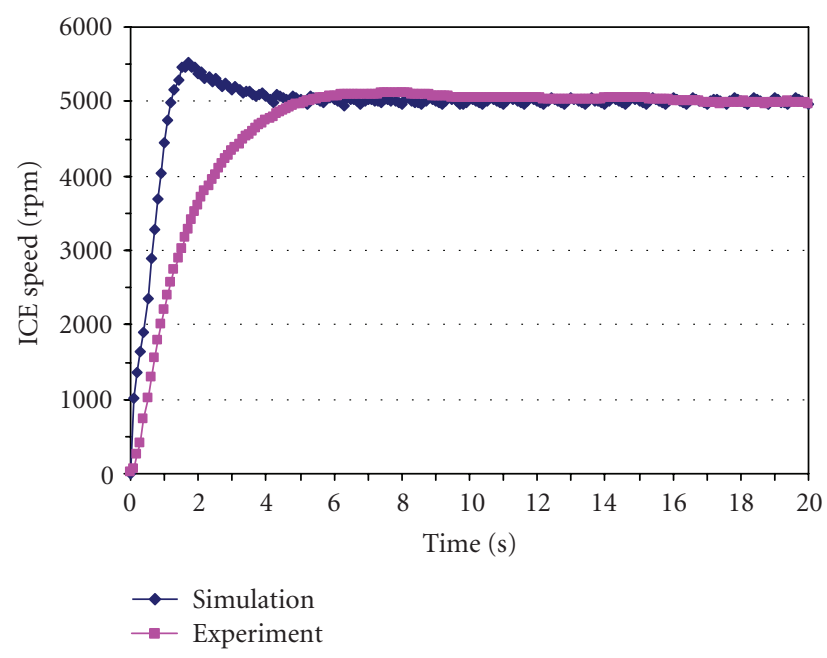

FIGURE 16: Validation results of ICE speed.

of two energy sources: one from the compressed air flow of the air storage tank and the other from the exhaust gas of the engine. If the throttle is too full, pressure at the CSA provided by the air storage tank is too high, and flow from the engine will be obstructed. Thus, despite the full aperture of the throttle, the efficiency of the whole system increases slightly.

The main cause of this phenomenon is that we are unable to take full advantage of the heat energy from the engine. In addition, sometimes exhaust gas flows backward because of the impact of high pressure from the air storage tank. This is very nonbeneficial to the engine on a practical level. At a fixed level of pressure in the air storage tank, the throttle's aperture gets smaller, resulting in a decrease in static pressure. Consequently, velocity increases considerably and energy is transformed from pressure energy into kinetic energy. This leads to an increase in static pressure in the CSA and an improvement in the circulation of exhaust gas flow as well as a combination of exhaust gas and compressed air that increases the regenerated exhaust gas energy. As a result, the whole system's efficiency increases significantly.

As can be seen in Figures 14 and 15, the change of throttle stands at $25 \%, 50 \%, 75 \%$, and $100 \%$ when the initial pressure in the storage tank reaches 12 bars. Apparently, at specific moments between 0 to $60 \mathrm{~s}$, there is a difference between the rates of decreases in velocity and throttle aperture. For example, in the 30th second, when the throttle aperture reaches $25 \%$ and $50 \%$, the vehicle's velocity stays at $37 \mathrm{~km} / \mathrm{h}$ and $64 \mathrm{~km} / \mathrm{h}$, respectively. However, at this time, the former is $50 \%$ and $75 \%$ and the latter is $64 \mathrm{~km} / \mathrm{h}$ and $81 \mathrm{~km} / \mathrm{h}$, respectively. After 65 seconds, the velocity remains stable at slightly higher than $60 \mathrm{Km} / \mathrm{h}$ of $25 \%$ throttle aperture, around $90 \mathrm{Km} / \mathrm{h}$., $98 \mathrm{Km} / \mathrm{h}$ and $105 \mathrm{Km} / \mathrm{h}$ of $50 \%, 75 \%$ and $100 \%$ throttle aperture, respectively. It is obvious that at this moment, the velocity of the vehicle reach to the stable condition accordant with the delivering form airtank as well as the ICE. The demand of high-pressure air from air turbine and thus, from vehicle will increase in the case of higher road resistance. 


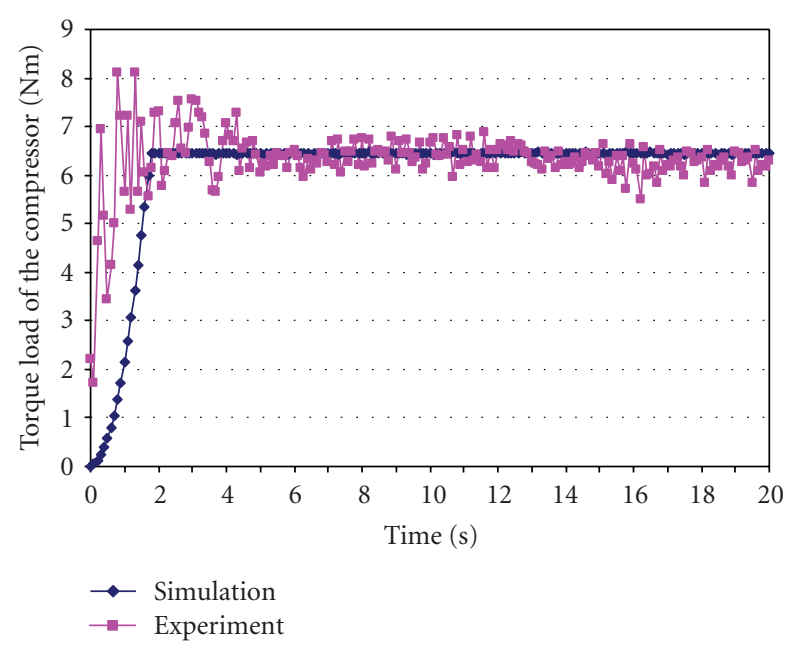

Figure 17: Validation results of Compressor Torque Load.

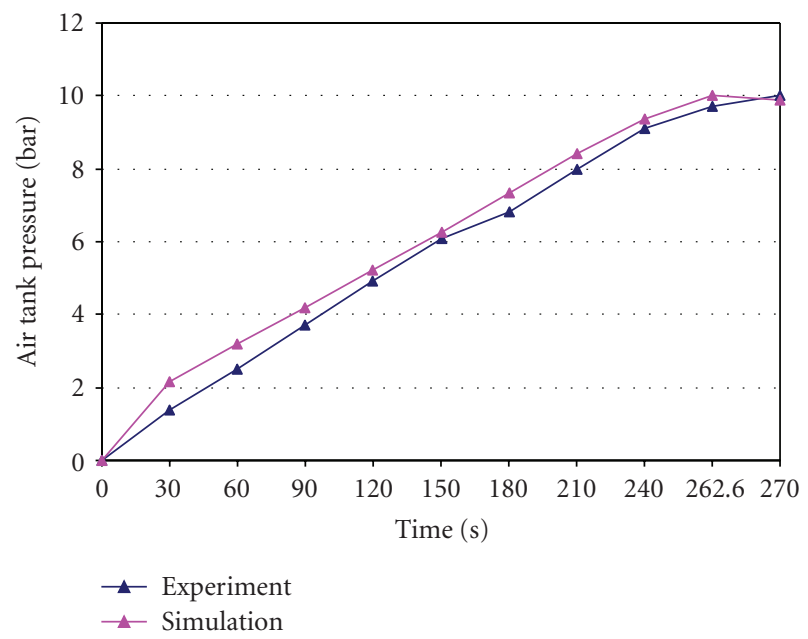

FIgURE 18: Filling up the air storage tank.

In brief, the decrease in energy is much greater than the decrease in the throttle aperture. So it is undoubted that the more the throttle aperture decreases, the greater the resistance force at the throttle, thus the whole system, increase. This results in the difference between the proportional increase or decrease in the throttle and velocity. Figure 15 illustrates the decrease in pressure with the initial air pressure system in the storage tank at 12 bars and the throttle's aperture remaining at $25 \%, 50 \%, 75 \%$, and $100 \%$, respectively. As analyzed above, pressure in the storage tank declines variously from 0 to $90 \mathrm{~s}$ in comparison with the decrease in the throttle from $100 \%$ to $25 \%$ from 0 to $75 \mathrm{~s}$. It's just because, besides the fall in the system's friction along with the increase in the throttle's aperture, the slight reduction in pressure is different at various throttle apertures, which results from similar speeds of compressed air provided by the air storage tank.

6.3. Validation Results. Figure 16 illustrates ICE speed results for both the experiment and the simulation. In the experi- ment, after operating for $6 \mathrm{~s}$, the engine's operation remains stable at $5000 \mathrm{rpm}$ with variation from 70 to $100 \mathrm{rpm}$. This results from the accelerator pedal adjustment by researchers and the instability of the platform, which causes vibration when the engine is operating and leads to the slight load. However, the result achieved is quite accurate in the simulation. In the simulation, under efficient load and stable operating conditions, the engine also reaches nominal speed by $4.1 \mathrm{~s}$. Apparently, as can be seen in the chart, the magnitudes of the values shown in the simulated chart and those found in the experiment are different when the engine starts to operate. This is because there is a difference between the inertias of the simulation and experiment. Speed changes rapidly in the model compared to the experiment, because the higher the inertia, the slower the change in cycles. This is proved when the stable speed occurs sooner in the model.

Figure 17 illustrates the axial load of the engine achieved in both the simulation and the experiment. In the experiment, the torque delivered to the air compressor also becomes stable, maintaining a stable load at $6.7 \mathrm{Nm}$ and actually fluctuating by $\pm 0.25 \mathrm{Nm}$ right after having worked at $5000 \mathrm{rpm}$, and the output pressure controlling valve stays at 10 bars. As can be seen, the significant initial variation as well as the fluctuation when the experiment curve becomes stable after $7 \mathrm{~s}$ results from the increasing round of friction of the whole system. This leads to a remarkable variation of the compressor affecting the whole engine. It declines considerably when the engine's cycling is in equilibrium and the system also reaches dynamic equilibrium. This is not illustrated in the chart because of the stability of the model compared with the practical experiment. The simulation curve stays at $6.7 \mathrm{Nm}$ after $3.5 \mathrm{~s}$.

The speed of reaching the pressure illustrated in Figure 18 reveals that the time required to fill up the air storage tank is much shorter than when using a battery cell. The initial design requires time to fill the air storage tank in order to reach the sufficient operating pressure for the vehicle which is less than 10 minutes. In the simulation as well as in the experiment, the use of the reciprocate compressor, which creates high pressure and high efficiency, makes the air storage tank reach the required pressure in a shorter time. The required time gets shorter if we have optimal parameters for the engine and compressor. As seen in the graph, in the experiment, the time taken to fill the air storage tank from the initial pressure to the required pressure set at 10 bars, when we can stop providing compressed air, is $270 \mathrm{~s}$.

The low variation in the experiment curve proves that provision of compressed air to the air storage tank is fast and stable, thanks to the stable operation of engine and air compressor. The time taken to fill the air storage tank for the simulation curve is $262.6 \mathrm{~s}$ shorter and tends to decrease because the air compressor stops providing compressed air accordant with the control signal. Furthermore, in a specific period of time, the pressure in the air storage tank in the simulation is always higher than in the experiment, which proves the greater stability of the model. 


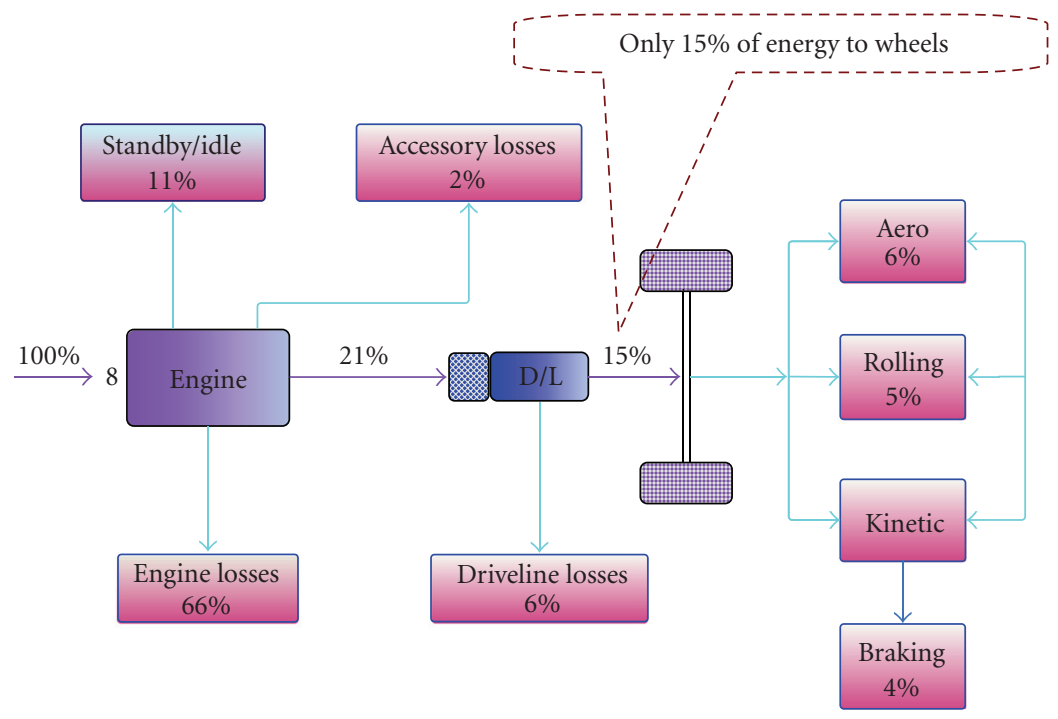

FIgURE 19: Energy efficiency diagram of conventional system.

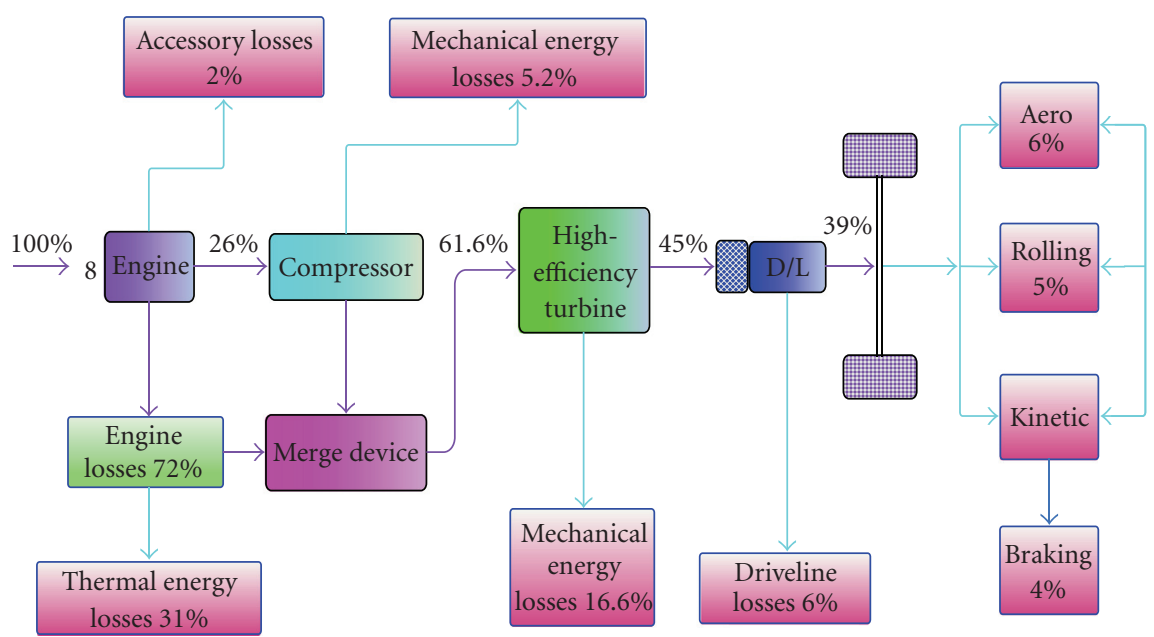

FIGURE 20: HPPS energy-efficiency calculation.

\section{Conclusion}

This research has analyzed the behavior of a HPPS. The construction of the system has not created new energy but optimized the use of the existing energy. From the Figures 19 and 20, the estimated calculation results from Ford Motor Corporation in 1997 for conventional vehicles, was compared with the experiment and simulation results of HPPS [refer to Appendix A], it is obvious that the energy lost has been greatly reduced. Consequently, all of the energy can be generated and applied to maximize the performance, so that the goals of reducing fuel consumption and exhaust emissions and lower costs may be achieved. The advantages of this system may be summarized as follows:

(i) The internal combustion engine can be maintained within an optimal operating range, and the waste gas and heat can be recycled. Thus, the pollution and fuel consumption of the internal combustion engine can be minimized.

(ii) Compared with an electric motor that may face the danger of overheating, the airturbine can provide overload protection, with a smaller time-constant and inertia/output ratio. Thus, it can be activated and stopped stably. Furthermore, in view of its power output, the control valve can be applied to control the torque and rotation speed.

(iii) This system features good scalability. Flywheel energy-storing devices and braking energy recycling devices can be installed to offset the shortcomings of low-energy density in order to enhance the overall efficiencies of the systems. 


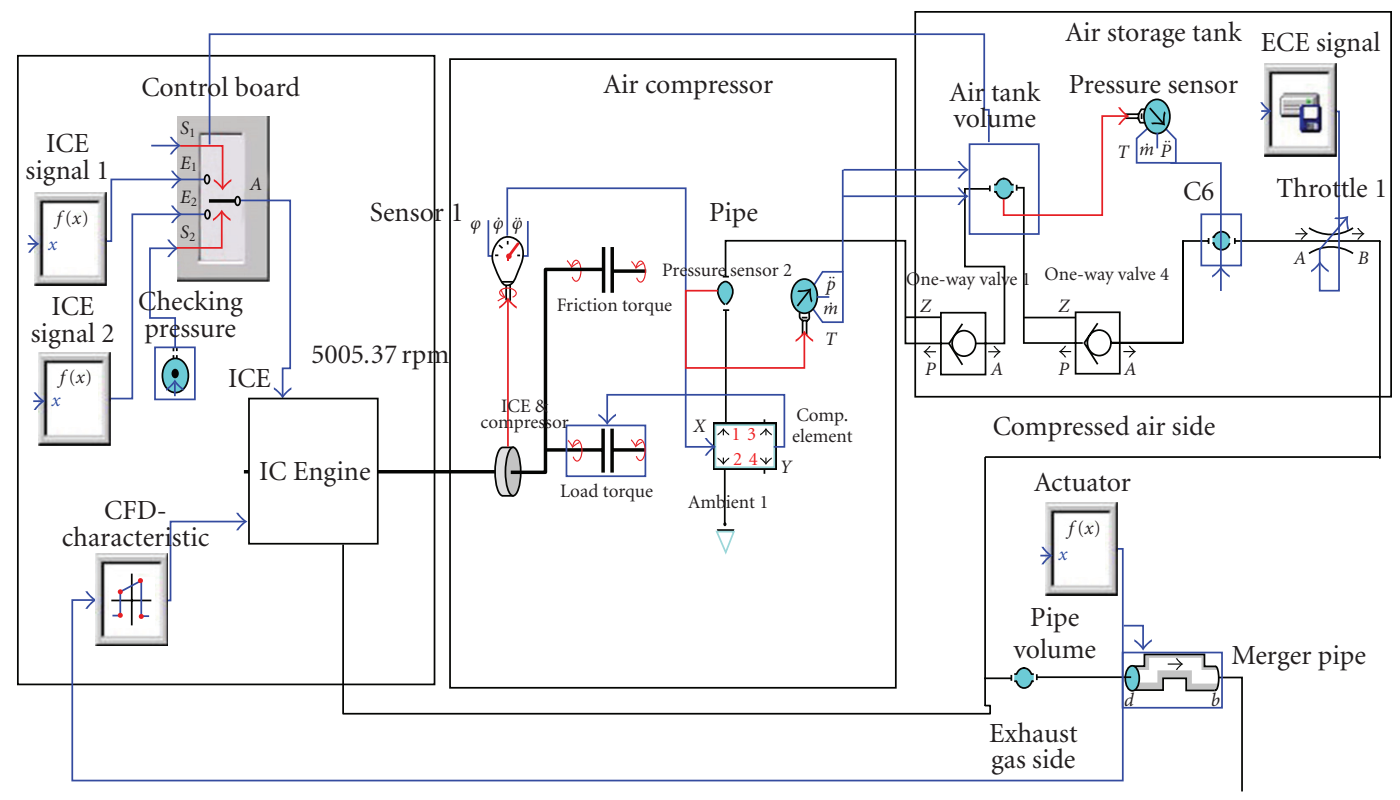

(a)

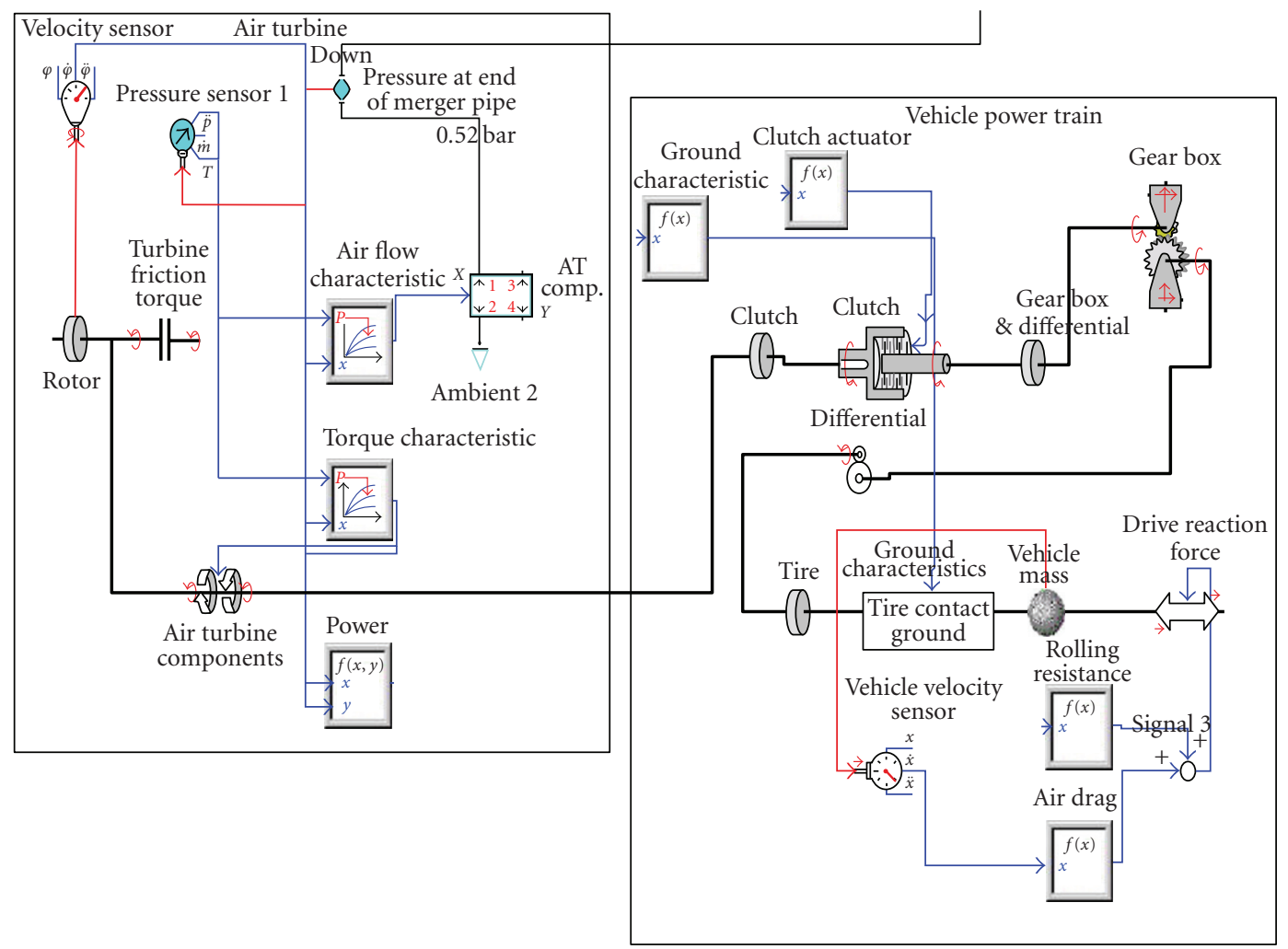

(b)

FIgURE 21

(iv) The experimental and simulation results show that a vehicle equipped with an HPPS could achieve efficiency approximately $35-39 \%$ higher than that of conventional vehicles.
Future work. In the next step of research procedure, research group will be going to carry out the experiments with diesel engines with the purpose of investigation for the advantages of heat efficiency of the recycled exhaust gas energy. Besides, 
the suitable air turbines for the system will be found and evaluated for full practical experiments, in order to make the entire design of the prototype from all available components. In addition, the regeneration system will also be integated for the next HPPS generation.

\section{Appendices}

\section{A. Calculation of Merger Flow Energy Efficiency of HPPS}

\section{A.1. Combustion Engine Efficiency}

\section{A.1.1. Supplying Fuel for ICE. One has}

$$
G_{f}=g_{e} \times P_{\mathrm{ICE}}
$$

where $\mathrm{G}_{f}$ : fuel consumption $(\mathrm{g} / \mathrm{s}), g_{e}$ : brake specific fuel consumption $(\mathrm{g} / \mathrm{kW} \cdot \mathrm{h}), P_{\mathrm{ICE}}$ : output power of the ICE $(\mathrm{kW})$.

\section{A.1.2. Energy of Supply Fuel for ICE. One has}

$$
E_{f}=Q_{H} \times G_{f},
$$

where $E_{f}$ : energy of supply fuel $(\mathrm{kJ} / \mathrm{s}), Q_{H}$ : heat of fuel $(\mathrm{kJ} / \mathrm{kg})$.

\section{A.1.3. Thermal Efficiency of the ICE. One has}

$$
\eta_{I C E}=\frac{P_{I C E}}{E_{I C E}} \times 100 \%,
$$

where $\eta_{I C E}$ : thermal efficiency (\%).

\section{A.2. Exhaust-Gas Recycling Efficiency. One has}

$$
\eta_{\mathrm{ex}-\mathrm{re}}=\frac{E_{\mathrm{ex}-\mathrm{re}}}{E_{f}} \times 100 \%,
$$

where $\eta_{\text {ex-re: }}$ exhaust-gas recycling efficiency, $E_{\text {ex-re }}$ : energy of the exhaust-gas flow.

$$
E_{\mathrm{ex}-\mathrm{re}}=\dot{m}_{\mathrm{ex}} \times\left(h_{\mathrm{ex}}+\frac{v_{\mathrm{ex}}{ }^{2}}{2}\right),
$$

where $\dot{m}_{\text {ex }}$ : mass rate of exhaust-gas flow $(\mathrm{kg} / \mathrm{s}), h_{\text {ex }}$ : enthalpy of exhaust-gas $(\mathrm{kJ} / \mathrm{kg}), v_{\mathrm{ex}}$ : the velocity of exhasut-gas flow $(\mathrm{m} / \mathrm{s})$.

A.2.1. Data Derived from Experimental Results. Based on the experimental result, exhaust-gas velocity, exhaust-gas temperature and exhaust-gas pressure have been identified.

A.2.2. Mass Flow Rate of Exhaust-Gas Flow. One has

$$
\begin{aligned}
& \dot{m}_{\mathrm{ex}}=v_{\mathrm{ex}} \times \rho_{\mathrm{ex}}, \\
& A_{\mathrm{pp}}=\frac{\pi \times D_{\mathrm{pp}}^{2}}{4},
\end{aligned}
$$

where $A_{w}$ : cross-sectional area of merger pipe, which is indicated in [13], $D_{\mathrm{pp}}$ : diameter of merger pipe, and ex $\rho$ is density of ehaust-gas flow and is defined as follows:

$$
\rho_{\mathrm{ex}}=\frac{P_{\mathrm{ex}}}{R \times T_{\mathrm{ex}}},
$$

where $P_{\text {ex }}$ : pressure of exhaust-gas flow $(\mathrm{kPa}), T_{\mathrm{ex}}$ : temperature of exhaust-gas $(\mathrm{K})$, and assumption the exhaustgas components are $\mathrm{CO} 2$ and $\mathrm{H} 2 \mathrm{O}$, thus $R$ is about 0.21 $(\mathrm{kJ} / \mathrm{kg} \cdot \mathrm{K})$.

A.2.3. Enthalpy of Exhaust-Gas. One has

$$
h_{\mathrm{ex}}=C_{p 0} \times T_{\mathrm{ex}},
$$

where $C_{p 0}$ is defined as follows:

$$
\begin{gathered}
C_{p 0}=C_{0}+C_{1} \theta+C_{2} \theta^{2}+C_{3} \theta^{3}, \\
\theta=\frac{T_{\mathrm{ex}}}{1000} .
\end{gathered}
$$

According to the [20, Table A.6], the $C_{0}, C_{1}, C_{2}$, and $C_{3}$ were made with the values correlative; $1.05,-0.365,0.85$, and -0.39 , respectively.

\section{A.3. Merger Device}

A.3.1. Merger Flow Energy. One has

$$
E_{\mathrm{mf}}=\dot{m}_{\mathrm{mf}} \times\left(h_{\mathrm{mf}}+\frac{v_{\mathrm{mf}}^{2}}{2}\right),
$$

where $\dot{m}_{\mathrm{mf}}$ : mass flow rate of merger flow $(\mathrm{kg} / \mathrm{s}), h_{\mathrm{mf}}$ : enthalpy of merger flow $(\mathrm{kJ} / \mathrm{kg}), \mathbf{v}_{\mathbf{m f}}$ : velocity of merger flow $(\mathrm{m} / \mathrm{s})$.

\section{A.3.2. Merger Flow Energy Efficiency. One has}

$$
\eta_{\mathrm{mf}}=\frac{E_{\mathrm{mf}}}{E_{f}} \times 100 \%,
$$

where $\eta_{\mathrm{mf}}$ : merger flow energy efficiency (\%), $E_{\mathrm{mf}}$ : energy of the merger flow $(\mathrm{kW})$.

\section{B. ITI-Sim Model of HPPS}

(See Figure 21) 


\section{Nomenclature}

BHP: $\quad$ Brake horsepower of the engine (PS)

$N: \quad$ Engine speed (rpm)

$T: \quad$ Engine torque $(\mathrm{Nm})$

$T_{0}$ : Ambient temperature $\left({ }^{\circ} \mathrm{C}\right)$

$T_{1}$ : $\quad$ Output pressure of compression $\left({ }^{\circ} \mathrm{C}\right)$

$W$ : Work done

n: $\quad$ Polytropic index

$P_{0}: \quad$ Ambient pressure (bar)

$P_{1}$ : $\quad$ Output pressure of compression (bar)

$R: \quad$ Gas constant $\left(\mathrm{J} \mathrm{K}^{-1} \mathrm{~mol}^{-1}\right)$

$\eta_{v}: \quad$ Volumetric efficiency

$K$ : $\quad$ Compressor factor

$V_{\mathrm{c}}: \quad$ Relative clearance volume

$p_{2}: \quad$ Delivery pressures in the first stage

$p: \quad$ Intake pressures in the first stage

$Z_{1}$ : $\quad$ Compressibility factor at intake

$Z_{2}$ : Compressibility factor at discharge

$m: \quad$ Index of expansion

$V_{\mathrm{r}}: \quad$ Receive size of air-storage-tank (1)

Q: $\quad$ Volume capacity $\left(\mathrm{m}^{3} / \mathrm{min}\right)$

$P_{\mathrm{d}}: \quad$ Discharge pressure (bar)

$\omega: \quad$ Angular velocity ( $\mathrm{rad} / \mathrm{s})$

$\Delta P: \quad$ Pressure difference (bar)

$M: \quad$ Inlet flow-rate $\left(\mathrm{m}^{3} / \mathrm{s}\right)$

$R_{a}: \quad$ Aerodynamic resistance $(\mathrm{N})$

$R_{r}: \quad$ Rolling resistance $(\mathrm{N})$

$\rho: \quad$ Mass density of the air $(\mathrm{kg} / \mathrm{m} 3)$

$C_{D}$ : Coefficient of aerodynamic resistance

$A_{f}: \quad$ Frontal area of the vehicle $\left(\mathrm{m}^{2}\right)$

$V_{r}: \quad$ Vehicle speed relative to the wind $(\mathrm{m} / \mathrm{s})$

$\mu_{r}: \quad$ Coefficient of rolling resistance

$W_{w}: \quad$ Vehicle's weight $(\mathrm{kg})$

$\lambda_{x}: \quad$ Slip coefficient

$A, B, K, r$ : Road condition coefficients.

\section{References}

[1] G. Maggetto and J. Van Mierlo, "Electric vehicles, hybrid electric vehicles and fuel cell electric vehicles: state of the art and perspectives," Annales de Chimie: Science des Materiaux, vol. 26, no. 4, pp. 9-26, 2001.

[2] K. Morita, "Automotive power source in 21st century," JSAE Review, vol. 24, no. 1, pp. 3-7, 2003.

[3] R. Priddle, Automotive fuels for the future. 21th International Energy Agency, IEA-AMF advanced motor fuels, 1999.

[4] M. J. Kellaway, "Hybrid buses-what their batteries really need to do," Journal of Power Sources, vol. 168, no. 1, pp. 95-98, 2007.

[5] H. Tsuchiya, "Innovative renewable energy solutions for hydrogen vehicles," International Journal of Energy Research, vol. 32, no. 5, pp. 427-435, 2008.

[6] "Moteur Development International (MDI)," http://www.mdi .lu/english/index.php.

[7] "Clean automotive technology program: developing cleaner and more efficient vehicles and engines for tomorrow," Tech. Rep. EPA420-R-06-008, November 2006.

[8] R. V. Basshuysen and F. Schafer, Internal Combustion Engine Handbook, Basics, Components, Systems and Perspectives, SAE International, Detroit, Mich, USA.
[9] C. Davis, B. Edelstein, B. Evenson, A. Brecher, and D. Cox, "Hydrogen fuel cell vehicle study," Tech. Rep., Panel on Public Affairs (POPA), Ameican Physical Society, 2003.

[10] N. Iwai, "Analysis on fuel economy and advanced systems of hybrid vehicles," JSAE Review, vol. 20, no. 1, pp. 3-11, 1999.

[11] J. V. Mierlo, G. Maggetto, and P. Lataire, "Which energy source for road transport in the future? A comparison of battery, hybrid and fuel cell vehicles," Energy Conversion and Management, vol. 47, no. 17, pp. 2748-2760, 2006.

[12] N. Iwai, "Analysis on fuel economy and advanced systems of hybrid vehicles," JSAE Review, vol. 20, no. 1, pp. 3-11, 1999.

[13] K. D. Huang, K. V. Quang, and K. T. Tseng, "Experimental study of flow energy merger of hybrid pneumatic power system," in Proceedings of the IEEE International Conference on Sustainable Energy Technologies (ICSET '08), pp. 1151-1156, Singapore, November 2008.

[14] K. D. Huang, K. V. Quang, and K.-T. Tseng, "Study of the effect of contraction of cross-sectional area on flow energy merger in hybrid pneumatic power system," Applied Energy, vol. 86, no. 10, pp. 2171-2182, 2009.

[15] P. Beater, Pneumatic Drives, Springer, Berlin, Germany, 2007.

[16] J. Y. Wong, Theory of Ground Vehicles, John Wiley \& Sons, New York, NY, USA, 3rd edition, 2001.

[17] Wohnhaas, Hotzer and Sailer, "VDI report Nr.1220 of the year $1995, "$ p. 106.

[18] “ITI-Sim 3.5 Manual,” 1998, ITI GmbH.

[19] "SAE paper advanced vehicle powertrains," Tech. Rep. SP1973, SAE International, 2005.

[20] R. E. Sonntag, C. Borgnakke, and G. J. Van Wylen, Fundamentals of Thermodynamics, John Wiley \& Sons, New York, NY, USA, 6th edition. 

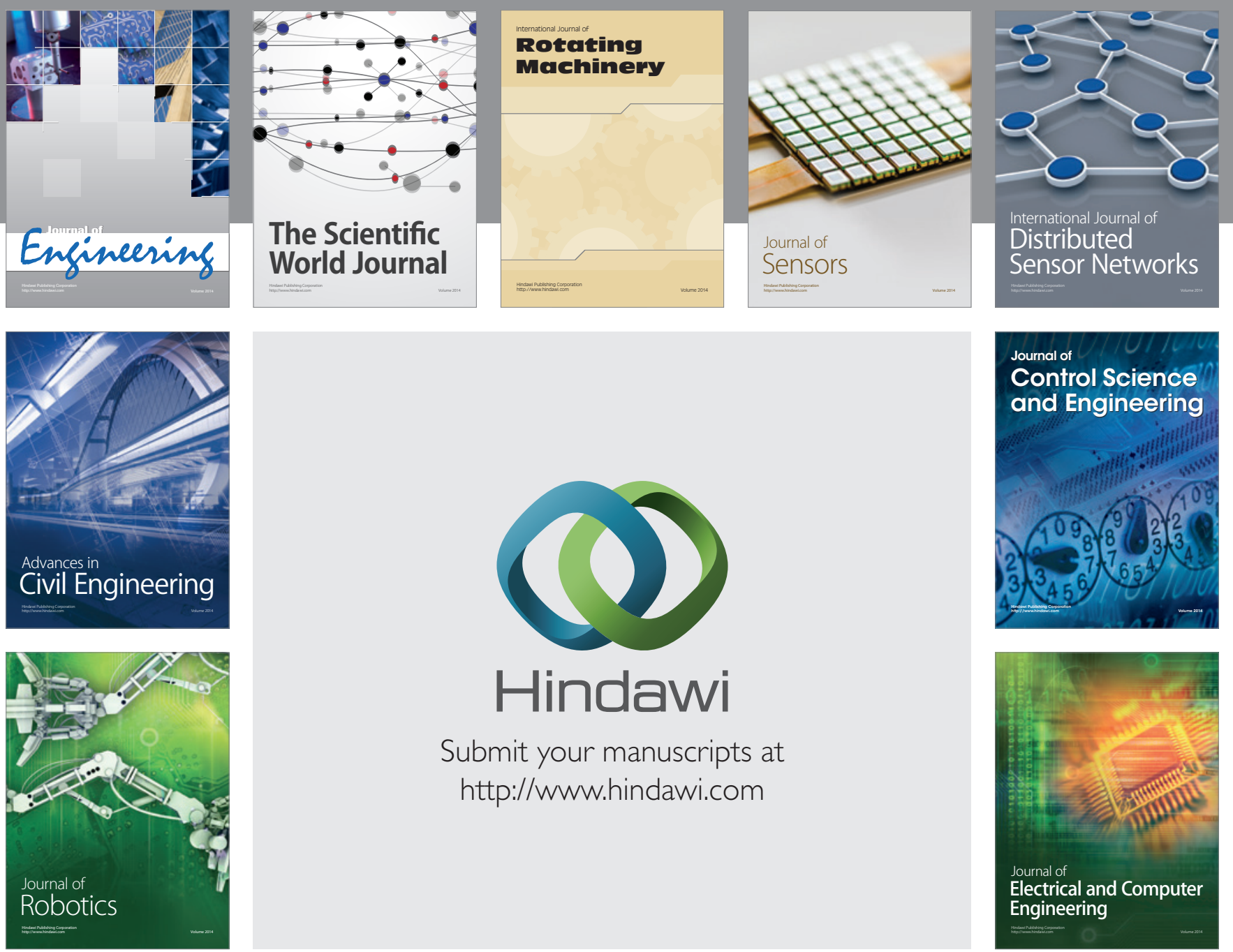

Submit your manuscripts at

http://www.hindawi.com
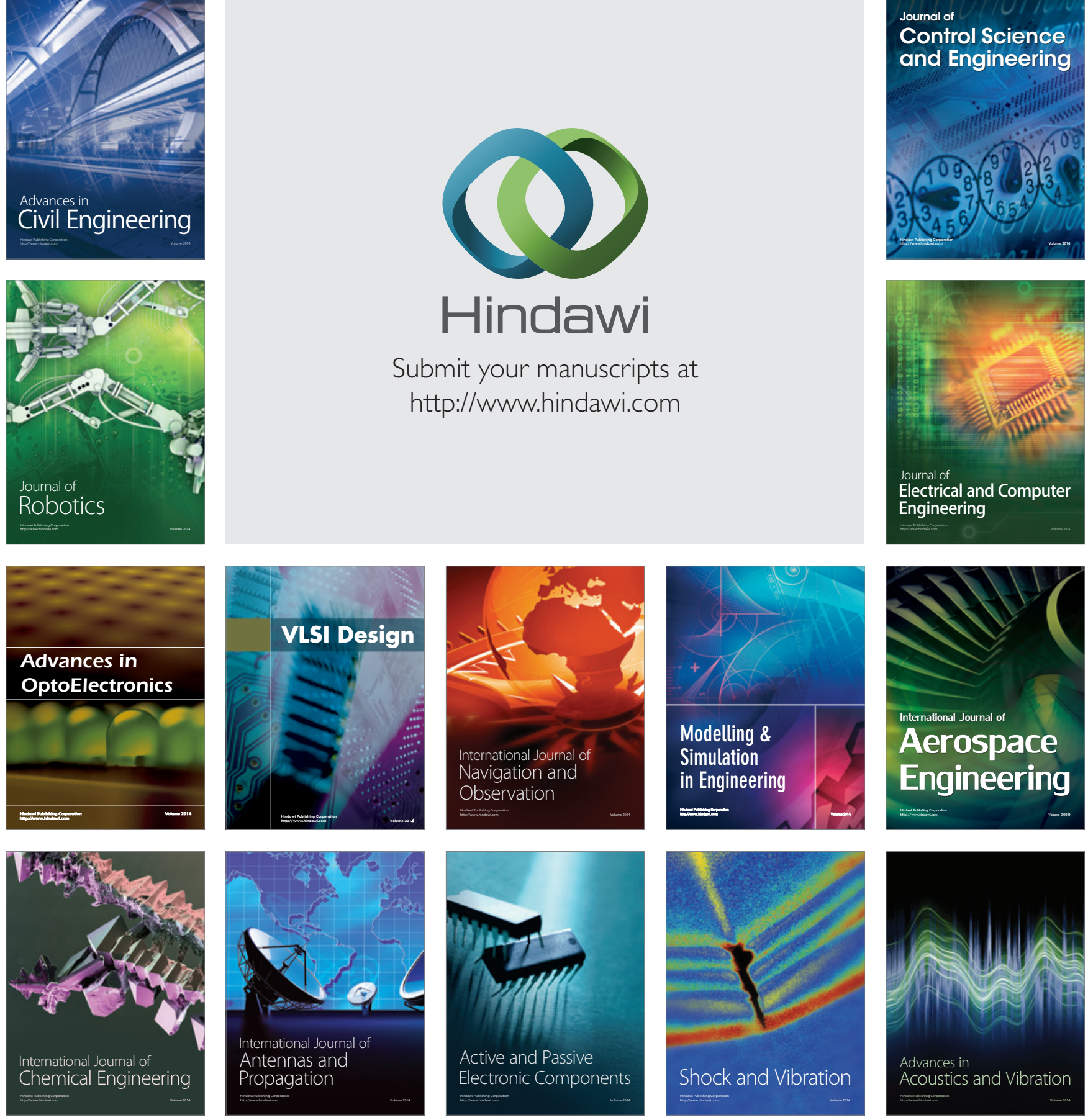